\title{
Middle School Teacher Professional Development in Creating a NGSS-plus- 5E Robotics Curriculum (Fundamental)
}

\section{Dr. Shramana Ghosh, NYU Tandon School of Engineering}

Shramana Ghosh received her Ph.D. in Mechanical Engineering from University of California, Irvine in 2017, her Masters in Industrial Engineering from Texas A\&M University in 2013, and her Bachelors in Manufacturing Processes and Automation Engineering from University of Delhi in 2011. She is currently working as a postdoctoral associate at the Mechanical and Aerospace Engineering Department, NYU Tandon School of Engineering, NY, USA. In this role she supports and studies use of robotics in K-12 STEM education. Her other research interests include robotics, mechanical design, and biomechanics.

\section{Mrs. Veena Jayasree Krishnan, NYU Tandon School of Engineering}

Veena Jayasree Krishnan received a Master of Technology (M. Tech.) degree in Mechatronics from Vellore Institute of Technology, Vellore, India in 2012. She has two years of research experience at the Indian Institute of Science, Bangalore, India. She is currently pursuing Ph.D. in Mechanical Engineering at NYU Tandon School of Engineering. She is serving as a research assistant under an NSF-funded DR K-12 research project to promote integration of robotics in middle school science and math education. For her doctoral research, she conducts mechatronics and robotics research in the Mechatronics, Controls, and Robotics Laboratory at NYU.

\section{Dr. Sheila Borges Rajguru, NYU Tandon School of Engineering}

Dr. Sheila Borges Rajguru is the Assistant Director of the Center for K-12 STEM Education, NYU Tandon School of Engineering. As the Center's STEAM educator and researcher she works with engineers and faculty to provide professional development to K-12 STEM teachers with a focus on social justice. She is currently Co-Principal Investigator on two NSF-grants that provide robotics/mechatronics PD to science, math, and technology teachers. In addition, she is the projects director of the ARISE program. This full-time, seven-week program includes: college level workshops and seminars, and a high level research experience in NYU faculty labs. Her commitment to diversity and equity is paramount to her work in STEAM and activism. As a former Adjunct Professor at Teachers College, Columbia University and biomedical scientist in immunology Dr. Borges balances the world of what scientists do and brings that to STEAM education in order to provide culturally relevant professional development and curricula that aligns to the Next Generation Science Standards (NGSS). Her free time is spent hiking, growing spiritually, and enjoying her family and friends. Moreover, Dr. Borges is treasurer and co-chair of the Northeastern Association for Science Teacher Education (NE-ASTE) where faculty, researchers, and educators inform STEM teaching and learning and inform policy.

\section{Dr. Vikram Kapila, NYU Tandon School of Engineering}

Vikram Kapila is a Professor of Mechanical Engineering at NYU Tandon School of Engineering (NYU Tandon), where he directs a Mechatronics, Controls, and Robotics Laboratory, a Research Experience for Teachers Site in Mechatronics and Entrepreneurship, a DR K-12 research project, and an ITEST research project, all funded by NSF. He has held visiting positions with the Air Force Research Laboratories in Dayton, OH. His research interests include K-12 STEM education, mechatronics, robotics, and control system technology. Under a Research Experience for Teachers Site, a DR K-12 project, and GK-12 Fellows programs, funded by NSF, and the Central Brooklyn STEM Initiative (CBSI), funded by six philanthropic foundations, he has conducted significant K-12 education, training, mentoring, and outreach activities to integrate engineering concepts in science classrooms and labs of dozens of New York City public schools. He received NYU Tandon's 2002, 2008, 2011, and 2014 Jacobs Excellence in Education Award, 2002 Jacobs Innovation Grant, 2003 Distinguished Teacher Award, and 2012 Inaugural Distinguished Award for Excellence in the category Inspiration through Leadership. Moreover, he is a recipient of 2014-2015 University Distinguished Teaching Award at NYU. His scholarly activities have included 
3 edited books, 9 chapters in edited books, 1 book review, 62 journal articles, and 154 conference papers. He has mentored 1 B.S., 35 M.S., and 5 Ph.D. thesis students; 58 undergraduate research students and 11 undergraduate senior design project teams; over $500 \mathrm{~K}-12$ teachers and 118 high school student researchers; and 18 undergraduate GK-12 Fellows and 59 graduate GK-12 Fellows. Moreover, he directs K-12 education, training, mentoring, and outreach programs that enrich the STEM education of over 1,000 students annually. 


\section{Middle School Teacher Professional Development in Creating a NGSS-plus- 5E Robotics Curriculum (Fundamental)}

\section{Introduction}

The persistent lack of diversity in science, technology, engineering, and math (STEM) fields remains a serious challenge for the U.S. global competitiveness. STEM jobs are growing 29\% faster than any other U.S. sector [1]. Yet, today, white men hold roughly $75 \%$ of all science and engineering jobs, despite making up only $26 \%$ of the total workforce [2]. The cause of this diversity gap can be traced to our educational system, where most children-of-color do not receive equitable public education due to high teacher attrition rates, thus limiting access to well-trained teachers and resulting in lack of school resources [3]. Moreover, "many...students are frustrated by an education they often find irrelevant and removed from the world of work" [4]. Such a disconnect and decoupling leads to a decrease in intrinsic motivation and disengagement in STEM fields [5].

To address the aforementioned concerns about STEM education, twenty-six states were involved in creating the national standards, the Next Generation Science Standards (NGSS) [6]. The recommendations for teaching and learning infused in these standards are grounded in voluminous research (by institutions, teachers, educators, scientists, engineers, researchers, etc.) that has sought to identify problems in science classrooms and examine myriad techniques for engendering engaging learning environments for students [7]. One unique aspect of the NGSS is the recognition of each standard as a Performance Expectation (PE). Moreover, each PE is made up of three dimensions: Disciplinary Core Ideas (DCIs), Cross Cutting Concepts (CCCs), and Science and Engineering Practices (SEPs). Through this framework of interconnected dimensions, the NGSS aims to support students to develop the capability to form explanatory models for key natural phenomena using scientific investigative methods, observations, and integration of prior knowledge. To teach students effectively under the NGSS framework, it is suggested that their prior knowledge be accessed and science misconceptions be identified to undergo a conceptual change, i.e., replacement with the correct scientific conceptualization [8]. The 5E instructional model (5Es) is widely used to help teachers organize their lesson content and activities coherently to facilitate such a conceptual change [9]. The 5E model constitutes the following sequential stages: Engage, Explore, Explain, Elaborate, and Evaluate.

The NGSS signals a significant divergence vis-à-vis traditional approaches to science education [7]. Hence, teacher professional development (PD) that addresses the transition from previous standards to NGSS is crucial. This paper describes the processes and results of developing a LEGO robotics, NGSS, and 5E aligned middle school curriculum during a three-week summer PD program for teachers who teach urban students belonging to groups underrepresented in STEM fields. This distinctive curriculum was developed and refined through a multi-stage process: (i) 
involving PD facilitator training; (ii) three dimensional NGSS curriculum development by teachers and facilitators; and (iii) teacher participants' support of other teachers. The study participants included six science and math teachers from New York City (NYC) middle schools who had previously undergone LEGO robotics PD at the NYU Tandon School of Engineering but lacked formal NGSS-plus-5E lesson development experience. This was done purposefully to focus on curriculum development for the new national standards. A qualitative case study [10] is used as a methodology for analysis. A sociocultural theoretical framework highlighting Bourdieu's social capital [11] and a critical constructivist perspective [12], [13] are used to describe the benefits of balancing the power of mentor-protégé relationship [14]. This bricolage is used to show that although PD facilitators have a grasp of science concepts and have knowledge about how to create NGSS-plus-5E lessons, teachers inform the pedagogy on how to teach concepts to middle school students. Teachers and PD facilitators shared human capital, which formed opportunities for them to create strong ties and learn from each other, thereby, socially constructing knowledge.

\section{Literature Review}

The framework for K-12 Science Education [15] and the NGSS [6] present a cohesive approach to learning science through the three interconnected dimensions represented by the DCIs, SEPs, and CCCs associated with a small number of critical PEs in science. The NGSS represents a shift from "knowing numerous science facts" to gaining a "deep understanding of complex ideas of science," which is critical since the framework [15] envisions preparing students to thrive in the modern technological age by inculcating the spirit of inquiry, investigation, and explanation in science education. This vision for science learning and teaching necessitates a dramatic and substantial departure from current teaching approaches in K-12 classrooms [16]. Prior research [17] suggests that within the educational system, the primary channels in which the influence of NGSS will be apparent are: curriculum, teacher development, and assessment. This indicates the importance of initial preparation as well as continuing PD for teachers. The NGSS explicitly requires integration of engineering practices in science learning environments, which has prompted researchers to suggest that a significant amount of teacher and administrator PD be carried out so that engineering does not become just another topic taught in a fragmented and siloed manner in accordance to the old approach [18]. Creators of the NGSS themselves explicitly state that "the immediate challenge that exists is the development of quality materials and building awareness and understanding for educators and communities" [19].

Teacher education is vital as the actual implementation of changes in any K-12 classroom ultimately rests on the shoulders of the educators. As the NGSS constitutes a substantial shift in teaching practices, beliefs, attitudes, and understanding, familiarizing teachers with the standards as well as equipping them with the necessary resources to effectively implement NGSS in their classrooms will be a major challenge. Researchers [7] suggest that any such teacher PD must focus on understanding the kind of concepts being taught in K-12 curriculum, how this knowledge is 
constructed, and what pre-requisites are needed for it to motivate teachers to develop new pedagogical approaches. In fact, Ref. [7] claims that learning about the NGSS by itself is insufficient, and teachers must be trained to conduct classroom activities that enact its practices. Other researchers have investigated the needs for research-based teacher PD for specific topics included in the NGSS such as climate change [20]. Their findings emphasize the need for highquality curriculum development, with focus on technology integration and hands-on activities that would be personally relevant to learners. In relation to the implementation of NGSS, researchers have also suggested making the connections to Common Core State Standards for English Language and Arts (ELA) and mathematics explicit [17].

The effective implementation of NGSS in classrooms will ultimately rely on teachers who have been provided with the appropriate resources, support, and training [17]. Unfortunately, many if not most teachers learned to teach using a model of teaching and learning that focuses heavily on memorizing facts and lacks an emphasis on deeper understanding of subject knowledge [21]. The primary way of providing training, resources, support, and educational opportunities to teachers is through PD. In the past few decades, education faculty and researchers [21]-[23] have focused their attention on understanding effective teacher PD strategies and their impact on teacher learning, yet research in this area is hampered by the lack of uniformity and comparable data in different projects. Studies with small PD programs conducted at a single site with teachers who volunteered to participate show that high quality PD can help teachers deepen their knowledge and improve their teaching [22]. Key characteristics of effective PD identified in the literature include: (i) sufficient duration; (ii) focus on subject matter; (iii) hands-on activities; (iv) attention to problems of practice; and (v) institutional support for implementation. It is further suggested that teacher learning is best promoted by a set of complementary approaches, such as summer PD and online discussions as follow up [24].

Traditionally, the focus of teacher PD programs has been on preparing teachers to follow, rather than to create or adapt, innovative, research-based curriculum materials [25]. However, when teachers do not understand the underlying model of the expert-designed curricula provided to them, they tend to pick and choose elements of the new curriculum to fit their existing classroom practices. To ensure that such adaptations do not under-cut the efficacy of well-designed material, it is essential to educate teachers regarding the underlying frameworks and engage them in the design of curricula [25]. Research suggests that involving teachers in curriculum development requires PD that actively engages them in the design of new context-based units [26]. A five-phase teacher PD model, created by researchers [27], to support such a process consists of: (i) dialogue about research and national goals; (ii) articulation of personal beliefs; (iii) design of curriculum; (iv) alignment of curriculum with school environment; and (v) design of assessments. Students taught by the teacher participants of such PD programs demonstrate better science attitudes and interest while maintaining performance in state tests [27]. This model of curriculum development also encourages teachers to take ownership of the content, reflect on the rationale for their 
practices, and invest in greater self-learning, all of which lead to the creation of educative curriculum materials [24]. Educative curriculum materials refer to curriculum that promotes teacher learning in addition to student learning by supporting and developing skills for instructional decision making.

With regard to the development of NGSS-aligned curriculum, researchers have suggested a 10step process [28]. It consists of: (i) selection of PEs related to a given topic or DCI; (ii) review of the PEs to establish the scope of instruction; (iii) examination the DCIs, SEPs, and CCCs of the selected PEs; (iv) examination of the DCIs to identify content ideas; (v) identification of additional SEPs; (vi) development of lesson level PEs; (vii) determination of acceptable evidence for assessing lesson level PEs; (vii) selection of related Common Core Standards; (ix) construction of a storyline; and $(\mathrm{x})$ review of developed lesson to ensure it encompasses the PE.

As discussed above, high quality curriculum development requires the use of a well-regarded instructional model. For our work, we select the 5E Instructional Model which is widely used for development of curriculum materials of various lengths and sizes, and has been extensively prescribed for teacher PD [9]. This model consists of the engage, explore, explain, elaborate and evaluate stages that take students through a learning progression to help them formulate an understanding of scientific concepts through engagement in hands-on activities. The first ' $E$ ' engages learners in a question that usually is a common science misconception. The second ' $\mathrm{E}$ '

provides students with activities in which the misconceptions are targeted, and conceptual change is facilitated. The third ' $E$ ' introduces new concepts to learners and helps them form explanations. The fourth ' $E$ ' provides educators the opportunity to challenge the learners' understanding of concepts and to strengthen and extend them. The final ' $E$ ' provides the opportunity to assess the learner's performance. As the learner goes through the journey of all the 5Es the science concept becomes clear.

The curriculum materials produced during this PD use LEGO-robotics as a tool to promote student engagement and learning. Robotics is increasingly being adopted as a ubiquitous tool to facilitate high-quality science education in K-12 classrooms in the U.S. Use of robotics for teaching math and science curriculum in schools has been shown to improve student engagement, problemsolving skills, and innovative thinking [29]. Thus, educational robotics is uniquely poised to support the vision of NGSS, specially the incorporation of engineering practices, and should form an integral part of new curriculum being designed to support the standards.

\section{Theoretical Framework}

This study is grounded in a sociocultural theoretical framework by building upon Bourdieu's theory of social capital [11], and the works of critical constructivism [12], [13], to inform how social interactions during the different phases of PD facilitate the exchange of knowledge. In the 
last few decades, constructivism [30] has emerged as an influential learning theory whose principles serve as the founding pillars for curriculum development and pedagogical techniques used in both teacher and student education contexts. Essentially, constructivism considers learning as the act of constructing knowledge. However, critical constructivism, in particular, is concerned with teaching, learning, knowledge production, and research and the complex interrelationships among them [12].

Social capital can be considered to consist of resources such as information, influence, and reinforcement that support individuals who belong to a social network through purposive actions [31]. This 'capital' is generated through investment by individual members of the social network, such as participants and facilitators of a teacher PD, in building trust and creating channels for mutual recognition and acknowledgement. The returns can be seen as resource exchange, creation of intellectual capital, and cross-functional team effectiveness [32]. Researchers have reported that the quality of teacher-student personal relations and teachers' enthusiasm for science teaching are important indicators for effective teaching [17]. Theories championed by social scientists attribute this to investing in social capital by individuals to generate returns [11], [31].

Having social capital is particularly beneficial because it confers access to all other types of capitals and resources among members of a particular group. In the context of mentor-protégé relationships (i.e., teacher-teacher or facilitator-teacher relationships), the protégé gains access to a more specialized or diverse set of information by virtue of the relationship structures created. Conversely, Portes [33] discovered that members of a tight knit social group may bar access to others who differ from them, thus limiting access to diverse knowledge. Consequently, it is necessary, during the PD, for the mentors or PD facilitators to bring together members of diverse groups, such as teachers with a particular subject expertise, with strong within-group ties and engender opportunities for building across-group bridges and to facilitate the dissemination and acquisition of specialized knowledge.

\section{Method}

This section presents details regarding the development, organization, and execution of a teacher PD program, grounded in research, to create NGSS-plus-5E aligned curriculum for middle schools. The goal of the PD was for teachers to learn about NGSS and develop new LEGO robotics-based lessons that were aligned to the 3D model of the NGSS. Connections to Common Core Sate ELA and mathematics standards were made explicit. The PD program was executed over a three-week duration during the summer of 2018. A three-stage mentor-protégé relationship development was incorporated as an integral part of the PD. This paper showcases an example of implementation of our research-backed PD and discusses success and lessons learned from the process. 
The PD program consisted of three distinct phases as shown in Figure 1: (i) Phase I - Facilitator PD (May 30, June 14, June 21, July 5, July 13, 2018); (ii) Phase II - Teacher PD (July 16 - August 3, 2018); and (iii) Phase III - Teacher as Facilitator Training (July 27, August 3, 2018).

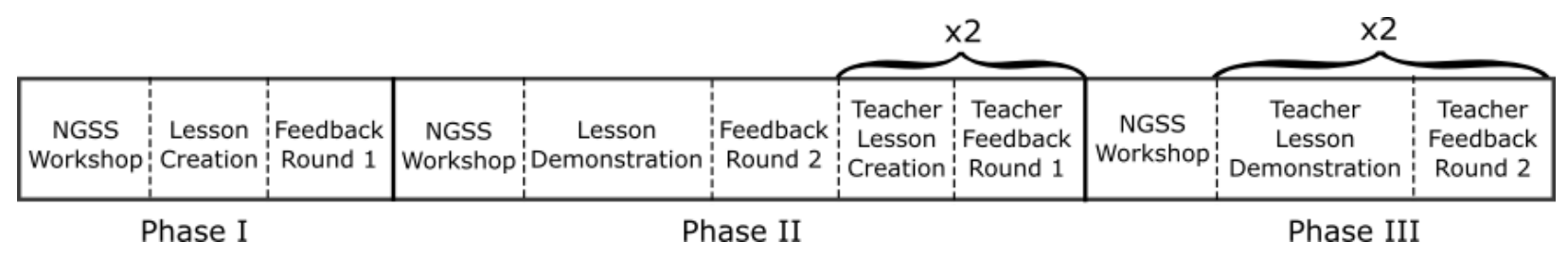

Figure 1: Details of the three-phase PD program

Phase I - Facilitator PD: The PD had four dedicated facilitators - two engineering graduate students and two engineering postdoctoral researchers, all of whom did not have prior experience of the NGSS. They were supported in their roles by an engineering faculty member and an education researcher. During the first phase, the education researcher and the faculty member, who have substantial expertise with NGSS acted as mentors, as shown in Figure 2. The education mentor shared online resources regarding NGSS and the 5E model with the PD facilitators via email on May 30, 2018 for self-study. A one-day workshop on NGSS and 5E instructional model was conducted for the facilitators by the education mentor on June 14, 2018. This is referred to as NGSS Workshop in Phase I in Figure 1. As a follow-up activity, the facilitators were tasked with studying LEGO robotics-enhanced science and math lessons previously created through NYU Tandon's work with middle school teachers to identify gaps in alignment with NGSS. For the following week, the education mentor met with the facilitators in an ongoing exchange supporting their needs and answering questions on how to use phenomena in NGSS, designing 5E lessons, and developing lessons using the three-dimensional model. On June 21, the mentors met with the facilitators to review their work, and each facilitator selected a single lesson that they would enhance and align with NGSS using a NGSS-plus-5E template provided to them by the education mentor. Facilitators also completed a daily reflection based on their experiences as they created the new NGSS-plus-5E aligned lessons. This period is referred to as Lesson Creation in Figure 1. On July 13, facilitators presented their lessons to other members of their team and the education and engineering faculty mentors and solicited their feedback. The facilitators then modified their lesson plans based on the ensuing discussions. This is referred to as Feedback Round 1 in Figure 1. This phase of the PD resulted in the creation of four NGSS-plus-5E lessons, whose details are provided in Table A.1 in Appendix A.

Phase II - Teacher PD: Participants for Phase II, labeled as the teacher PD, were selected from a group of NYC teachers who had previously attended a LEGO robotics related PD at NYU Tandon. Potential participants $(\approx 45)$ were contacted by email and informed of the opportunity four months before the start date of the PD. Six middle school teachers-three science and three math teachers - were selected to participate in the program. Their basic demographic information is 
provided in Table 1. After the completion of the program, one of the participating science teachers joined a high school but has continued to participate in the program. Principals of the schools from which teachers were selected endorsed their participation. All participants were provided stipends. They were required to be present in person at NYU Tandon five days a week from 8:30 am-5:00 pm for the duration of the PD. Each participant completed a daily reflection at the end of each day of the PD.

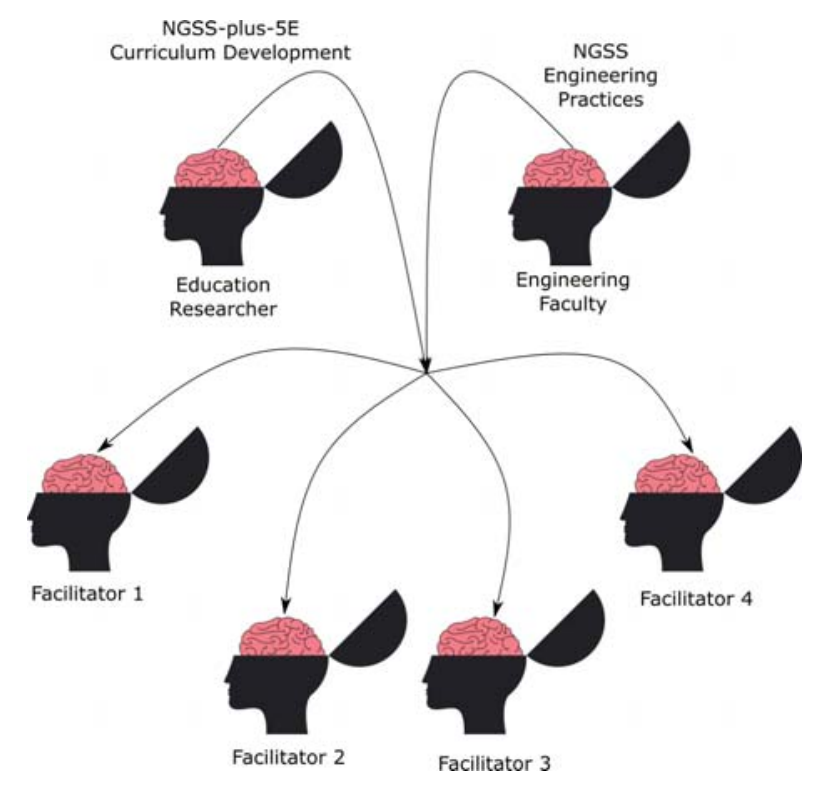

Figure 2: Illustration of mentor-protégé relationships developed during Phase I

Table 1: Details of participating teachers

\begin{tabular}{|c|c|c|}
\hline Teacher Alias & Subject & Gender \\
\hline Teacher 1 & Math & F \\
\hline Teacher 2 & Science & F \\
\hline Teacher 3 & Science & F \\
\hline Teacher 4 & Math & F \\
\hline Teacher 5 & Math & M \\
\hline Teacher 6 & Science & F \\
\hline
\end{tabular}

On the first day of the teacher PD, the education mentor conducted a one-day NGSS-plus-5E workshop for the participating teachers. This is referred to as NGSS Workshop in Phase II in Figure 1. After the one-day workshop, the following four days of the first week were dedicated to demonstrating the NGSS-plus-5E lessons of Table A.1 by the facilitators. Each day a single facilitator presented her/his lesson and led the discussion on how well the lesson addressed the stated standards as well as obtained feedback from the participants regarding suggested improvements based on their broad experience of teaching middle-school students. This is referred to as Feedback Round 2 in Figure 1. At the end of this process, the four LEGO robotics-based 
NGSS-plus-5E lessons created by the facilitators were finalized and shared with all PD participants for their reference and use.

Next, in Week 2, the six teachers were divided into two groups, as indicated in Figure 3, and were asked to enhance and align one of their past lessons to the NGSS. Following two days of lesson creation by the teachers, the third day was dedicated to feedback process in which facilitators, other teachers, multiple engineering and education faculty members, and the education mentor participated in providing feedback to each group of teachers who presented their lesson. This is referred to as Teacher Feedback Round 1 in Figure 1. On the fourth day of the week the teachers modified their lessons based on the extensive feedback they received from their mentors. A similar schedule was repeated during Week 3. This phase of the PD resulted in the creation of four additional LEGO robotics-enhanced NGSS-plus-5E lessons (see Table A.2 in Appendix A). Throughout the three weeks of the PD, the facilitators also conducted LEGO robotics lessons and programming challenges for the teachers to refresh and update their knowledge and skills. The various mentor-protégé relationships that came in play during this phase of the PD are illustrated in Figure 3.

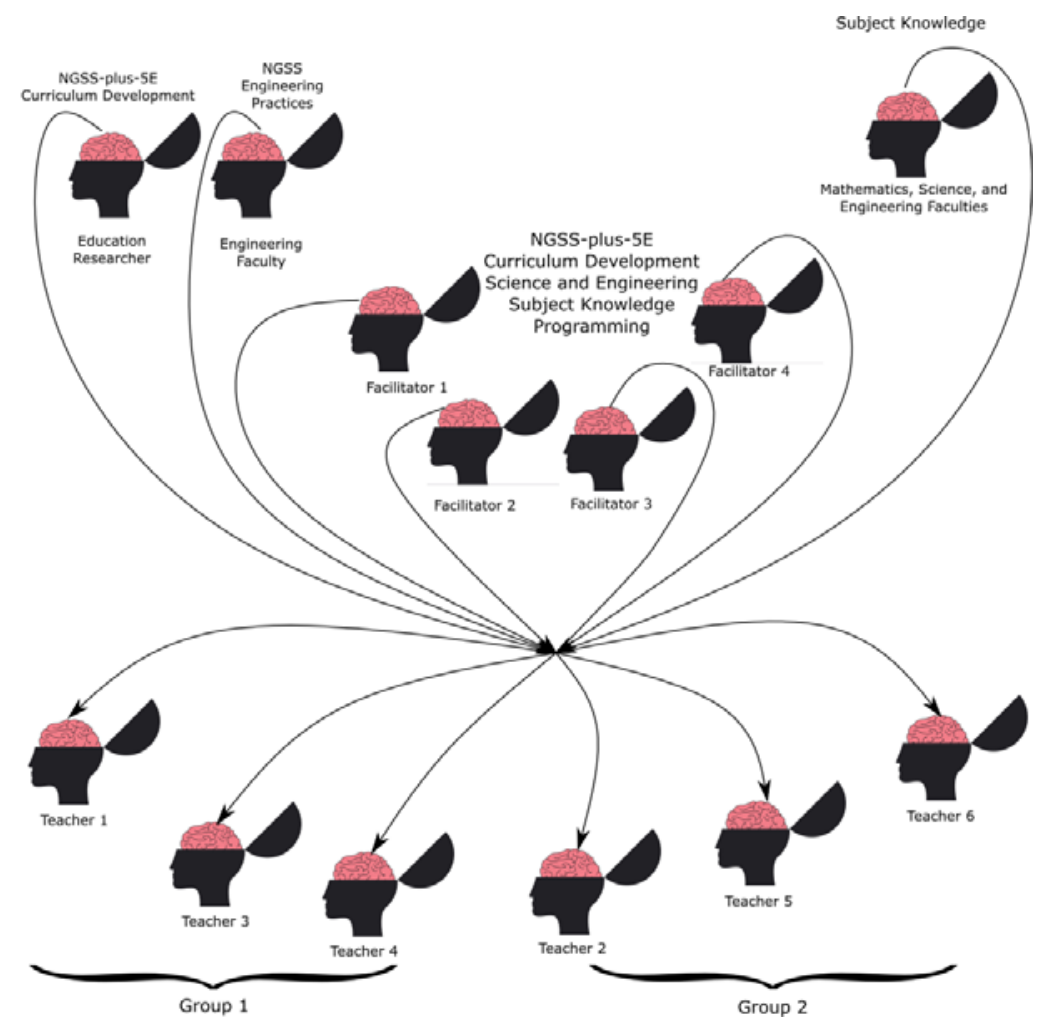

Figure 3: Illustration of mentor-protégé relationships developed during Phase II

Phase III - Teacher as Facilitator Training: Eleven NYC public-school teachers participating in an engineering education and research program at NYU Tandon were participants in this portion 
of the PD. They also participated in the one-day NGSS-plus-5E workshop conducted on the first day of Phase II of the PD. Following this, on the fifth day of Weeks 2 and 3 of the PD, the six teachers from the Phase II of the program held single day PDs on the creation of NGSS-plus-5E lessons for these eleven teachers. This component of the PD provided the teachers from Phase II the opportunity to demonstrate the lessons that they had created during that week to the group of protégé teachers. They discussed their work and solicited the opinions and feedback from their peers regarding it. This process is presented as Teacher Feedback round 2 in Figure 1. The relationships developed during this phase of the PD are shown in Figure 4.

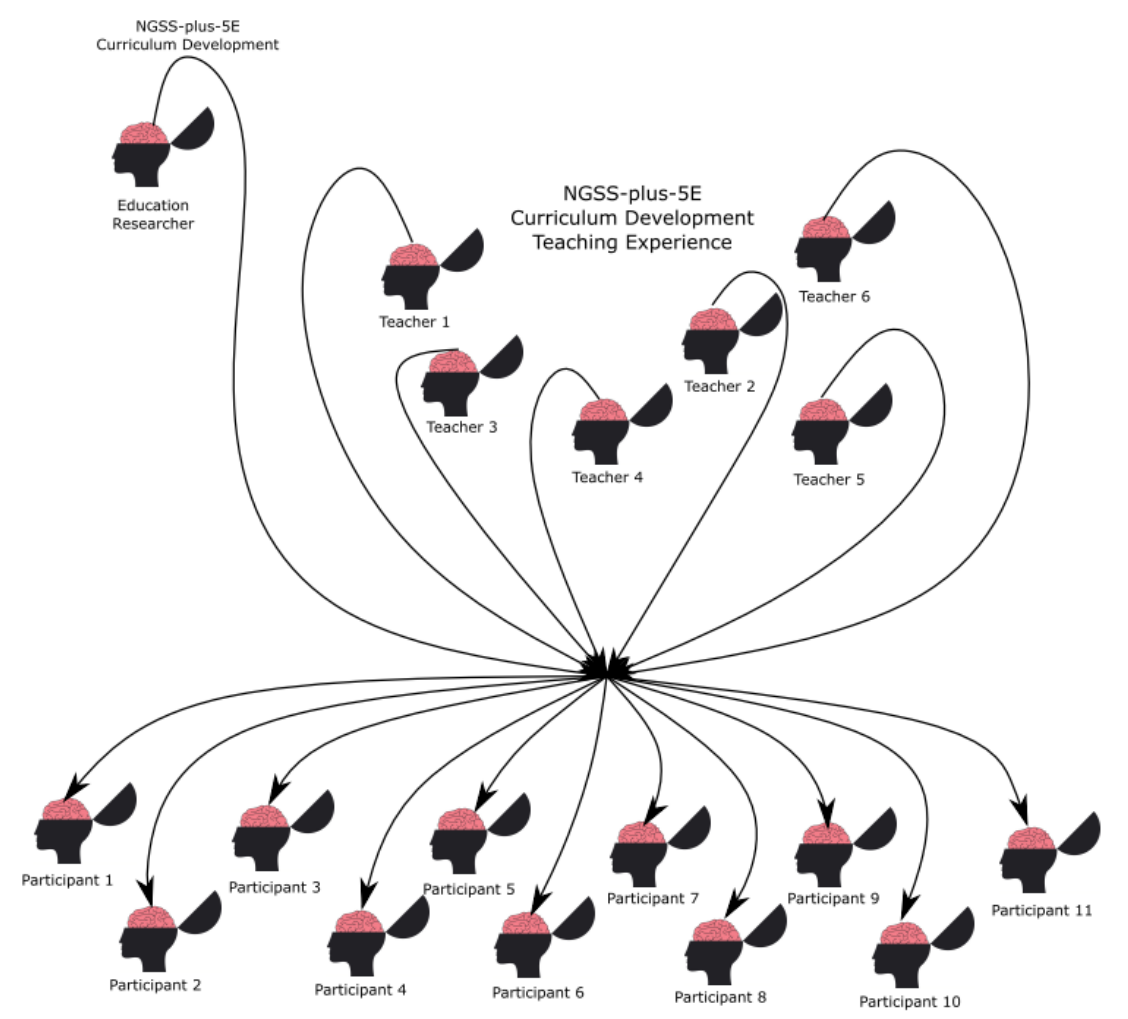

Figure 4: Illustration of mentor-protégé relationships developed during Phase III

\section{Data Analysis and Results}

This section analyzes the PD program based on the daily reflections written by both the facilitators and teachers, as well as extensive field notes taken by the facilitators during Phases II and III of the PD. The facilitator and teacher reflections were collected online by the education mentor, who then anonymized the data using aliases. The teachers were also asked to anonymously complete a pre- and post-survey (created by the facilitators and research and faculty mentors) regarding their knowledge of NGSS. Data analysis was conducted in two stages: (i) ongoing, to modify the PD content to best support participants' in their conceptualization of NGSS-plus-5E robotic lessons by addressing concerns expressed in reflections and focus groups, and (ii) summative, using 
grounded theory [10] as a method to identify categories by coding all data sources and finding themes. The research team analyzed the outcomes of the entire PD and identified three major themes: teacher resistance to NGSS, challenges in NGSS-plus-5E implementation, and science and math identity.

Teacher Resistance to NGSS: It has been well documented by many researchers that the NGSS demands a shift in both educational thinking as well as pedagogical tools and processes used by teachers in K-12 classrooms [17], [20]. Based on this, we anticipated that the process of adaptation and implementation of the standards will be accompanied by many misconceptions and resistance, on the part of all parties involved, requiring a deliberate effort to identify and address the same. To this end, a one-day NGSS-plus-5E workshop was conducted by the experienced education mentor for both the facilitators (Phase I) as well as the teachers and participants (Phase II/III). However, some teachers continued to exhibit a resistance to learning about the vision, developmental process, and structure of the NGSS even during the one-day workshop. Some participants acknowledged that their resistance was because they lacked clarity about the standards. Through sustained discussions, it was discovered that the need for a nuanced understanding of the standards only becomes apparent to some during their active participation in the curriculum development process. At the end of the study, data from the post-PD survey illustrates that teachers learned about the 3D model of the NGSS and the 5E instructional model. These gains persisted to the end of the program for most participants.

Challenges in NGSS-plus-5E Implementation: One of the most significant aspects of NGSS is that the PEs require integration of the three dimensions [17]. We found that both the facilitators and teachers struggled in many ways due to the rigor required by the standards, as illustrated in Table 2. Social capital [31] generated through peer support was found to be quite helpful in overcoming these challenges.

Incorporating 'old' lessons: After receiving the initial NGSS-plus-5E one-day workshop, the facilitators strategized for creating new lessons by using their previously designed robotics lessons (aligned to the Common Core Standards) and "trying to fit them" to the new NGSS-plus-5E lesson template. They had difficulty in identifying the appropriate PEs to use for the lessons as PEs in NGSS are in direct contrast to the old standards that aimed at equipping students with a multitude of facts about scientific topics without developing their knowledge, understanding, or skills about how to independently acquire and apply such information [7]. Through multiple discussions with their mentors, i.e. the education researcher and faculty mentors, as well as with their own peers, the facilitators were able shift their conceptualization to the new student-centered and phenomenabased NGSS-plus-5E robotics lessons. An example of one such lesson is presented in Table A.3 in Appendix A. Similarly, the facilitators mentored the teachers as they tried to negotiate their old lessons and find ways to plug them in one of the three dimensions of the NGSS. 
Incorporating three dimensions of the NGSS: Both teachers and facilitators struggled with creating LEGO-robotics activities and other curriculum materials that met all three dimensions of the selected PEs. Participants often attempted to repackage activities from old lessons. However, they soon realized that they needed to consciously modify such activities or design new activities to ensure that the SEPs and CCCs associated with the PEs were being met. In addition, during a facilitator lesson presentation in Phase I, facilitators struggled with the question "Should there be a Lego EV3 robotic activity for [each of the] [three dimensions] of the NGSS?" The consensus was that since previous research indicates robotic activities enhance student engagement [29], the facilitators would create lessons such that the robotic activities would address each of the three dimensions of a standard/PE. In the robotics lessons summarized in Tables A.1 and A.2 in Appendix A, each lesson explicitly addressed the DCIs, SEPs, and CCCs specified in the corresponding PEs. However, this approach constrained the SEPs to only the scientific practices of experimentation and observation specified in the PEs under consideration. Nonetheless, several robotics-based lessons explicitly address engineering practices through the $5 \mathrm{E}$ components elaborated in Tables A.1 and A.2. In future development, greater attention ought to be devoted to conceiving robotics activities that sufficiently incorporate engineering practices such as defining problems and designing solutions. The challenges faced by the PD facilitators and teachers clearly illustrate that one-day NGSS PD is not enough to make the shift from the Common Core State Standards for Science to the NGSS. Intensive and rigorous practice of addressing each of the three dimensions of NGSS along with the incorporation of engineering practices is necessary.

How to incorporate 5E's: Many teachers were concerned about the rigor of creating lessons by following a $5 \mathrm{E}$ framework. The illustration of facilitator created lessons during Week 1 of the PD helped them observe first-hand the utility of the framework in addressing student misconceptions. It was also found that teachers had challenges negotiating how to meet the $5 \mathrm{E}$ model requirements while still completing the lessons within a typical 45-minutes teaching period. A consensus was developed through multiple discussions that a lesson would be divided into two 45-minute sessions to meet the NGSS-plus-5E robotics lesson requirement. By the end of Week 3 of Phase II of the PD, greater acceptance was noticed among the participants towards both the NGSS and the use of the $5 \mathrm{E}$ instructional model.

Science and Math Identity: Science teachers usually have strong ties, due to social capital, with other science teachers as they share similar resources and struggles in the science classroom, and vice versa for math teachers. However, such tight social capital can bar access from others penetrating their dense networks, as illustrated by Portes [33].

Teacher Identities: Initially math teachers were unsure about their role in the NGSS-plus-5E lesson development, and facilitators noted marked disinterest by math teachers during demonstration of biology lessons. However, with support from the facilitators and the education researcher, the teachers realized that their different subject area expertise enhanced their overall conceptualization 
of middle school teaching and learning. For example, math teachers found that if the performance expectation of the lesson is carefully selected, it can include significant component of mathematics to the point that such lessons can be taught almost independently in a math class.

Engineer-Teacher Identities: In addition to identity issues regarding area of specialization among the teachers, similar concerns were noted among the facilitators. As specified previously, the four dedicated facilitators for the PD were graduate students and postdoctoral researchers in engineering fields. However, as the PD progressed, the facilitators began to develop a greater appreciation for the work done by the teachers. This illustrates an effective, bidirectional operationalization of social capital with facilitators and teachers learning from one-another.

For each of the aforementioned themes, Table 2 below provides examples of key issues affecting teachers during the PD while Table 3 provides examples of changes induced and observed in both the participants and facilitators.

Table 2: Key issues affecting teachers during PD identified through qualitative data analysis

\begin{tabular}{|l|l|l|}
\hline Emergent Themes & \multicolumn{1}{|c|}{ Elements } & \multicolumn{1}{c|}{ Key Quotes } \\
\hline \multirow{4}{*}{ Resistance } & $\begin{array}{l}\text { Explicit study of } \\
\text { standards }\end{array}$ & $\begin{array}{l}\text { "Even though I believe in standards-driven lessons, I believe that } \\
\text { studying the standards explicitly will not help in teaching a rich } \\
\text { lesson." }\end{array}$ \\
\hline \multirow{4}{*}{$\begin{array}{l}\text { Challenges in } \\
\text { NGSS-plus-5E } \\
\text { implementation }\end{array}$} & $\begin{array}{l}\text { Incorporating } \\
\text { 'old' lessons }\end{array}$ & $\begin{array}{l}\text { "I could not find a good standard for basing a lesson completely on } \\
\text { [my old lesson on] gear ratios." }\end{array}$ \\
\cline { 2 - 3 } & $\begin{array}{l}\text { three dimensions } \\
\text { of NGSS }\end{array}$ & $\begin{array}{l}\text { "It was particularly challenging to think of an activity that would not } \\
\text { only be about the topic but would also ensure that the specific SEP } \\
\text { was being met. I also had to research the concepts at a much greater } \\
\text { detail than I had initially anticipated." }\end{array}$ \\
\cline { 2 - 4 } & $\begin{array}{l}\text { How to } \\
\text { incorporate 5E's }\end{array}$ & $\begin{array}{l}\text { "I was a little afraid of [Facilitator 4]'s lesson plan. It was so detailed } \\
\text { and wordy. I don't think I would have the stamina or the attention } \\
\text { span to create a lesson plan like [them]." }\end{array}$ \\
\hline \multirow{5}{*}{$\begin{array}{l}\text { Science and math } \\
\text { identity }\end{array}$} & $\begin{array}{l}\text { "I don't want to explain [this] to my students [using] more } \\
\text { mathematical explanation like integration etc. I [would] go with } \\
\text { simple explanation, such as when force increases, the speed } \\
\text { increases." }\end{array}$ \\
\cline { 2 - 4 } & $\begin{array}{l}\text { Engineer-teacher } \\
\text { identities }\end{array}$ & $\begin{array}{l}\text { "I am finding it difficult to focus on reading about NGSS. I do not } \\
\text { find it very interesting to know about middle school curriculum and } \\
\text { different standards. But I liked going through the science concepts. } \\
\text { It's refreshing to recollect concepts I learned years ago." }\end{array}$ \\
\hline
\end{tabular}


Table 3: Examples of resolution of issues identified through qualitative data analysis

\begin{tabular}{|c|c|c|c|}
\hline $\begin{array}{c}\text { Emergent } \\
\text { Themes }\end{array}$ & Elements & Resolution & Key Quotes \\
\hline Resistance & $\begin{array}{l}\text { Explicit } \\
\text { study of } \\
\text { standards }\end{array}$ & $\begin{array}{l}\text { One-day NGSS-plus- } \\
\text { 5E workshop } \\
\text { Active participation in } \\
\text { curriculum } \\
\text { development }\end{array}$ & $\begin{array}{l}\text { “... [it] helped me understand the format of a NGSS } \\
\text { lesson...even though I felt that I understood it from } \\
\text { previous professional [development] sessions before, } \\
\text { I clearly have a much better understanding now." }\end{array}$ \\
\hline \multirow{3}{*}{$\begin{array}{l}\text { Challenges in } \\
\text { NGSS-plus-5E } \\
\text { implementation }\end{array}$} & $\begin{array}{l}\text { Incorporating } \\
\text { 'old' lessons }\end{array}$ & $\begin{array}{l}\text { Illustrations by } \\
\text { mentors and peers }\end{array}$ & $\begin{array}{l}\text { "After seeing [Facilitator 3]'s lesson, I got more } \\
\text { ideas about how to make my lesson... [they] clearly } \\
\text { explained how each section aligned with NGSS } \\
\text { 3Ds." }\end{array}$ \\
\hline & $\begin{array}{l}\text { Incorporating } \\
\text { three } \\
\text { dimensions } \\
\text { of NGSS }\end{array}$ & $\begin{array}{l}\text { Mentor and peer } \\
\text { feedback }\end{array}$ & $\begin{array}{l}\text { "Our presentation (Teacher Feedback Round 1) } \\
\text { generated a great deal of discussion. It made me } \\
\text { realize how tightly [the 3Ds have to be] aligned, } \\
\text { building on other components of the lesson. The } \\
\text { comments and recommendations helped us to } \\
\text { develop an even better lesson than we [had] initially } \\
\text { written." }\end{array}$ \\
\hline & $\begin{array}{l}\text { How to } \\
\text { incorporate } \\
5 \mathrm{E} \text { 's }\end{array}$ & $\begin{array}{l}\text { Lesson creation and } \\
\text { feedback }\end{array}$ & $\begin{array}{l}\text { "My frame of mind for lesson planning is more } \\
\text { structured, as I think of each of the } 5 \text { E components I } \\
\text { need to address. I will be rewriting my lesson during } \\
\text { upcoming month." }\end{array}$ \\
\hline \multirow{2}{*}{$\begin{array}{l}\text { Science and } \\
\text { math identity }\end{array}$} & $\begin{array}{l}\text { Teacher } \\
\text { identities }\end{array}$ & $\begin{array}{l}\text { Discussions with } \\
\text { mentors } \\
\text { Cooperative team } \\
\text { work }\end{array}$ & $\begin{array}{l}\text { "I can see myself teaching this [Earth Science] } \\
\text { lesson, with minor modifications, in my math class. I } \\
\text { could do this in alignment to the science teachers" } \\
\text { calendar." }\end{array}$ \\
\hline & $\begin{array}{l}\text { Engineer- } \\
\text { teacher } \\
\text { identities }\end{array}$ & $\begin{array}{l}\text { Interaction among } \\
\text { facilitators and } \\
\text { teachers }\end{array}$ & $\begin{array}{l}\text { "I learned many things about how to write a good } \\
\text { lesson. The teachers write every step and idea very } \\
\text { precisely in their lesson plan." }\end{array}$ \\
\hline
\end{tabular}

\section{Discussion and Conclusions}

This paper has presented the structure, organization, and execution of a three-stage PD for middle school teachers with the aim of creating NGSS-plus-5E curriculum that can be used by the participants in their classrooms. The PD utilized mentor-protégé relationships at several levels to transfer knowledge of NGSS and 5E lessons from experienced education researchers and faculty members to novice members of the group. The protégés are experienced researchers and teachers, with subject matter proficiencies or teaching experiences, who integrated their knowledge and expertise to support other novices or their own peers. The three phases and the mentor-protégé relationships developed therein are characterized in detail. Moreover, the social networks formed at each of the three stages of the PD were observed and the flow of information, influence, and reinforcement within the networks were documented. 
In the early stages of the teacher PD, a fair amount of initial resistance to the adoption of the NGSS was evidenced from the participating teachers, who wanted to use the framework but not the standards. In fact, they expressed the desire to package their own standards to match previous content that they had created. It is possible that teachers found the rigor and time it will take to create such lessons to be taxing. As seen in this study, all facilitators and teachers initially tried to plug previous lessons into a NGSS PE. Whenever that was not possible, they identified a different $\mathrm{PE}$ to make use of their existing resources. Another factor contributing to participants' resistance could be an inadequate appreciation and understanding for the cohesive 3D structure of the NGSS and its implications. This could also explain why teachers and facilitators initially tried to utilize previously existing resources, as is, without deeply thinking about the recommendations provided in the SEPs, DCIs, and CCCs of a particular PE. However, by the end of the three weeks of the PD, the teachers learned more about the utility and scope of the NGSS and how to create lessons using the 5E model. It is critical to point out the importance of teachers supporting each other when creating NGSS-plus-5E lessons. Creating strong ties with other teachers and facilitators was a significant contribution to designing new lessons. By using the framework of social capital to assign teachers into two groups of science and math teachers, results indicated that both groups enhanced each other's lesson planning. In fact, math teachers in the study initiated contact with their schools' science teachers to coordinate with them on how to incorporate their new found NGSS-plus-5E knowledge.

As opposed to the 10-step process of [28], practical experience during Phase I of the PD revealed that the following sequence worked effectively and was thus suggested for adoption in the later phases of the PD: (i) selection of PEs related to a given topic; (ii) review of the 3D components of PEs and 5E model; (iii) examination of DCIs to ensure that the selected PEs are sufficiently addressed; examination of the (iv) SEPs and (v) CCCs of the selected PEs to determine structure of lesson and to identify content ideas; (vi) construction of a storyline using the 5E model; and (vii) consideration of related Common Core Standards.

Based on our experiences from this study, we offer the following recommendations to PD providers and curriculum developers. First, the PD providers need to be aware that resistance could be present in some teachers when learning to create NGSS-aligned lessons. Second, there is a need to ensure that PD providers integrate illustrations of successful classroom implementations of NGSS-plus-5E lessons to promote teacher interest and buy-in. Third, providing opportunities to PD participants for developing lessons that address their perceived classroom needs can help engender interest and ownership in adopting such lessons for classroom implementation. Fourth, organizing a structured framework for PD participants to collaborate in lesson development can distribute the workload of formulating detailed lesson plans and promote peer learning. Fifth, creating avenues that engage PD participants to practice their newly acquired knowledge and experience with other teachers enhances their articulation of the NGSS, specifically by a recognition for and validation of the potential of NGSS to fundamentally change classroom 
practices and culture. Embedding opportunities for PD participants to teach other teachers are particularly relevant for PD programs that use the model of engineering experts as PD facilitators. It will be beneficial to formally examine the effectiveness of PD programs wherein participants become mentors of their peers.

\section{Acknowledgments}

This work is supported in part by the National Science Foundation grants DRK-12 DRL: 1417769, RET Site EEC: 1542286, and ITEST DRL: 1614085; and NY Space Grant Consortium grant 76156-10488. The authors thank the 17 NYC teachers for their participation in this study.

\section{References}

[1] S. Fayer, A. Lacey, and A. Watson, "STEM occupations: Past, present, and future," in Spotlight on Statistics, U.S. Bureau of Labor Statistics, 2017, pp. 1-35.

[2] R. Noonan, "STEM jobs: 2017 update (ESA Issue Brief \# 02-17)." US Department of Commerce, Economics and Statistics Administration, Office of the Chief Economist, Washington, DC, 2017.

[3] B. Scafidi, D. L. Sjoquist, and T. R. Stinebrickner, "Race, poverty, and teacher mobility," Economics of Education Review, vol. 26, no. 2, pp. 145-159, 2007.

[4] W.C. Symonds, R. Schwartz, and R.F. Ferguson, "Pathways to prosperity: Meeting the challenge of preparing young Americans for the 21st century." Harvard University Graduate School of Education, Cambridge, MA, pp. 1-53, 2011.

[5] N. Brickhouse, "Bringing in the outsiders: Reshaping the sciences of the future," Journal of Curriculum Studies, vol. 26, no. 4, pp. 401-416, 1994.

[6] NGSS Lead States, Next Generation Science Standards: For States, by States. Washington DC: National Academies Press, 2013.

[7] B.J. Reiser, "What professional development strategies are needed for successful implementation of the Next Generation Science Standards?," 2013.

[8] M.T.H. Chi, J.D. Slotta, and N. DeLeeuw, "From things to processes: A theory of conceptual change for learning science concepts," Learning and Instruction, vol. 4, pp. 27-43, 1994.

[9] R.W. Bybee et al., The BSCS 5E Instructional Model: Origins and Effectiveness. Colorado Springs, CO: BSCS, 2006.

[10] S.B. Merriam and E.J. Tisdell, Qualitative Research: A Guide to Design and Implementation. John Wiley \& Sons, 2015.

[11] P. Bourdieu, "The forms of capital," in Handbook of Theory and Research for the Sociology of Education, J. Richardson, Ed. New York, NY: Greenwood Publishing Group, 1986, pp. 241-258.

[12] J.L. Kincheloe, Critical Constructivism Primer. New York, NY: Peter Lang, 2005.

[13] C.S. Malott and B.J. Porfilio, Critical Pedagogy in the TwentyFirst Century: A New Generation of Scholars. Charlotte, N.C.: Information Age Publishers, 2011.

[14] C.A. Hansman, "Adult learning theories in mentoring relationships and models," in Theory and Practice of Adult and Higher Education, V.C.X. Wang, Ed. Charlotte, N.C.: Information Age Publishing, 2017, pp. 215241.

[15] National Research Council, A Framework for K-12 Science Education: Practices, Crosscutting Concepts and 
Core Ideas. Washington, DC: National Academies Press, 2012.

[16] E.R. Banilower et al., Report of The 2012 National Survey of Science and Mathematics Education. Chapel Hill, NC: Horizon Research, Inc., 2013.

[17] R.W. Bybee, "NGSS and the next generation of science teachers," Journal of Science Teacher Education, vol. 25, no. 2, pp. 211-221, 2014.

[18] T.J. Moore, K.M. Tank, A.W. Glancy, and J.A. Kersten, "NGSS and the landscape of engineering in K-12 state science standards," Journal of Research in Science Teaching, vol. 52, no. 3, pp. 296-318, 2015.

[19] S.L. Pruitt, "The Next Generation Science Standards: The features and challenges," Journal of Science Teacher Education, vol. 25, no. 2, pp. 145-156, 2014.

[20] E. Hestness, R.C. McDonald, W. Breslyn, J.R. McGinnis, and C. Mouza, "Science teacher professional development in climate change education informed by the Next Generation Science Standards," Journal of Geoscience Education, vol. 62, no. 3, pp. 319-329, 2014.

[21] M.S. Garet, A.C. Porter, L. Desimone, B.F. Birman, and K.S. Yoon, "What makes professional development effective? Results from a national sample of teachers," American Educational Research Journal, vol. 38, no. 4, pp. 915-945, 2001.

[22] H. Borko, "Professional development and teacher learning: Mapping the terrain," Educational Researcher, vol. 33, no. 8, pp. 3-15, 2004.

[23] A.J. Wayne, K.S. Yoon, P. Zhu, S. Cronen, and M.S. Garet, "Experimenting with teacher professional development: Motives and methods," Educational Researcher, vol. 37, no. 8, pp. 469-479, 2008.

[24] E. A. Davis and J. S. Krajcik, "Designing educative curriculum materials to promote teacher learning," Educational Researcher, vol. 34, no. 3, pp. 3-14, 2005.

[25] W. R. Penuel, L. P. Gallagher, and S. Moorthy, "Preparing teachers to design sequences of instruction in earth systems science: A comparison of three professional development programs," American Educational Research Journal, vol. 48, no. 4, pp. 996-1025, 2011.

[26] M. J. Stolk, O. de Jong, A. M. W. Bulte, and A. Pilot, "Exploring a framework for professional development in curriculum innovation: Empowering teachers for designing context-based chemistry education," Research in Science Education, vol. 41, no. 3, pp. 369-388, 2011.

[27] H. M. Parke and C. R. Coble, "Teachers designing curriculum as professional development: A model for transformational science teaching," J Res Sci Teach, vol. 34, no. 8, pp. 773-789, 1997.

[28] J. Krajcik, S. Codere, C. Dahsah, R. Bayer, and K. Mun, "Planning Instruction to Meet the Intent of the Next Generation Science Standards," Journal of Science Teacher Education, 2014.

[29] L.P.E. Toh, A. Causo, P.-W. Tzuo, I.-M. Chen, and S.H. Yeo, "A review on the use of robots in education and young children," Journal of Educational Technology \& Society, vol. 19, no. 2, pp. 148-163, 2016.

[30] P.E. Doolittle and W.G. Camp, "Constructivism: The career and technical education perspective," Journal of Career and Technical Education, vol. 16, no. 1, pp. 1-19, 1999.

[31] N. Lin, "Building a Network Theory of Social Capital," CONNECTIONS, vol. 22, no. 1, pp. 2-8, 1999.

[32] P.S. Adler and S.-W. Kwon, "Social capital: Prospects for a new concept," The Academy of Management Review, vol. 27, no. 1, pp. 17-40, 2002.

[33] A. Portes, "Social capital: Its origins and applications in modern sociology," Annual Review of Sociology, vol. 24, no. 1, pp. 1-24, 1998. 


\section{Appendix A}

Table A.1: Details of robotics-based NGSS-plus-5E lessons created by Facilitators in Phase I

\begin{tabular}{|c|c|c|c|}
\hline \# & \multicolumn{3}{|c|}{ Lesson } \\
\hline \multirow{9}{*}{1} & \multicolumn{3}{|l|}{ Topic: Scale of the Solar System } \\
\hline & \multicolumn{3}{|l|}{ Grade/Grade Band: $8^{\text {th }}$} \\
\hline & \multicolumn{3}{|c|}{$\begin{array}{l}\text { Lesson Description: Students record and analyze orbital period data and infer the order of planets in the solar } \\
\text { system based on their proximity to the Sun. LEGO robots are used form a scaled model of the solar system by } \\
\text { simulating the orbital motion of planets. }\end{array}$} \\
\hline & \multicolumn{3}{|c|}{ Performance Expectation(s): MS-ESS1-3 } \\
\hline & $\begin{array}{l}\text { Science \& Engineering Practices } \\
\text { (SEPs) }\end{array}$ & Disciplinary Core Ideas (DCIs) & Crosscutting Concepts (CCCs) \\
\hline & Analyzing and Interpreting Data & $\begin{array}{l}\text { ESS1.B: Earth and the Solar } \\
\text { System }\end{array}$ & Scale, Proportion, and Quantity \\
\hline & \multicolumn{3}{|c|}{$\begin{array}{l}\text { Common Core State Standards (CCSS) } \\
\text { ELA/Literacy - RST.6-8.1, RST.6-8.7 } \\
\text { Mathematics - MP.2, 6.RP.A.1, 7.RP.A.2 }\end{array}$} \\
\hline & \multicolumn{3}{|c|}{$\begin{array}{l}\text { Robotics Activity: Students observe time taken by a LEGO robot (displaying the name of each of the four } \\
\text { inner planets on the EV3 brick) to complete one orbit around a selected point (sun). Given the actual orbital } \\
\text { period of earth, students work in groups to calculate the orbital periods of the other three planets based on the } \\
\text { data collected. }\end{array}$} \\
\hline & \multicolumn{3}{|c|}{$\begin{array}{l}\text { 5E Model: } \\
\text { Engage: Students discuss how to infer the relative position of earth in the solar system. } \\
\text { Explore: Students observe the time taken by the earth orbit the sun using a scaled model of the solar system. } \\
\text { Explain: Students recognize that the closer an object is to the sun the shorter will be its orbital period. } \\
\text { Elaborate: Students approximate orbital periods for different planets using scaled model of solar system. } \\
\text { Evaluate: Students analyze actual data for the orbital periods of all the planets (anonymized) and use it to order } \\
\text { the planets based on their proximity to the sun and identify them. }\end{array}$} \\
\hline \multirow[t]{9}{*}{2} & \multicolumn{3}{|c|}{ Topic: Newton's Laws of Motion (1st and 2nd laws) } \\
\hline & \multicolumn{3}{|l|}{ Grade/Grade Band: $6^{\text {th }}-8^{\text {th }}$} \\
\hline & \multicolumn{3}{|c|}{$\begin{array}{l}\text { Lesson Description: Students observe and identify balanced and unbalanced forces acting on a body through } \\
\text { LEGO robot-based activities. They also investigate the effect of the mass of an object on its motion through } \\
\text { robotic activities. }\end{array}$} \\
\hline & \multicolumn{3}{|c|}{ Performance Expectation(s): MS-PS2-2 } \\
\hline & $\begin{array}{l}\text { Science \& Engineering Practices } \\
\text { (SEPs) }\end{array}$ & \begin{tabular}{|l} 
Disciplinary Core Ideas (DCIs) \\
\end{tabular} & Crosscutting Concepts (CCCs) \\
\hline & $\begin{array}{l}\text { Planning and Carrying Out } \\
\text { Investigations }\end{array}$ & PS2.A: Forces and Motion & Stability and Change \\
\hline & \multicolumn{3}{|c|}{$\begin{array}{l}\text { Common Core State Standards (CCSS) } \\
\text { ELA/Literacy - RST.6-8.3, WHST.6-8.7 } \\
\text { Mathematics - 6.EE.A.2, 7.EE.B.3, 7.EE.B.4 }\end{array}$} \\
\hline & \multicolumn{3}{|c|}{$\begin{array}{l}\text { Robotics Activity: Teams of students play a game of tug-of-war with two LEGO robots. They change settings } \\
\text { such as power levels or external weight added on the robot and observe which robot wins the game each time. }\end{array}$} \\
\hline & \multicolumn{3}{|c|}{$\begin{array}{l}\text { 5E Model: } \\
\text { Engage: Students observe different objects and discuss if the forces are balanced or unbalanced. } \\
\text { Explore: Students investigate settings of LEGO robots to win a game of tug-of-war. } \\
\text { Explain: Students determine how to predict an object's stability, continued motion, and changes in motion. } \\
\text { Elaborate: Students explore using external weights on robots to modify robots in a game of tug-of-war. } \\
\text { Evaluate: Groups of students redesign LEGO robots and compete to win in a game of tug-of-war. }\end{array}$} \\
\hline
\end{tabular}




\begin{tabular}{|c|c|c|c|}
\hline \multirow{2}{*}{\multicolumn{4}{|c|}{ Grade/Grade Band: $6^{\text {th }}-8^{\text {th }}$}} \\
\hline & & & \\
\hline & \multicolumn{3}{|c|}{$\begin{array}{l}\text { Lesson Description: Students observe the effects of different types of forces on the motion of objects and } \\
\text { relate them to the Newton's laws of motion. }\end{array}$} \\
\hline & \multicolumn{3}{|c|}{ Performance Expectation(s): MS-PS3-1, MS-PS3-2, MS-PS3-5 } \\
\hline & $\begin{array}{l}\text { Science \& Engineering Practices } \\
\text { (SEPs) }\end{array}$ & Disciplinary Core Ideas (DCIs) & Crosscutting Concepts (CCCs) \\
\hline & $\begin{array}{l}\text { MS-PS3-1: Analyzing and } \\
\text { Interpreting Data } \\
\text { MS-PS3-2: Developing and Using } \\
\text { Models } \\
\text { MS-PS3-5: Engaging in Argument } \\
\text { from Evidence }\end{array}$ & $\begin{array}{l}\text { MS-PS3-1 } \\
\text { PS3.A: Definitions of Energy } \\
\text { MS-PS3-2 } \\
\text { PS3.A: Definitions of Energy } \\
\text { PS3.C: Relationship Between } \\
\text { Energy and Forces } \\
\text { MS-PS3-5 } \\
\text { PS3.B: Conservation of Energy } \\
\text { and Energy Transfer }\end{array}$ & $\begin{array}{l}\text { MS-PS3-1: Scale, Proportion, and } \\
\text { Quantity } \\
\text { MS-PS3-2: Systems and System } \\
\text { Models } \\
\text { MS-PS3-5: Energy and Matter }\end{array}$ \\
\hline & \multicolumn{3}{|c|}{$\begin{array}{l}\text { Common Core State Standards (CCSS) } \\
\text { ELA/Literacy - RST.6-8.1, RST.6-8.7; SL.8.5; WHST.6-8.7 } \\
\text { Mathematics - MP.2, 6.RP.A.2, 7.RP.A.2, 8.EE.A.1, 8.EE.A.2, 8.F.A.3 }\end{array}$} \\
\hline & \multicolumn{3}{|c|}{$\begin{array}{l}\text { Robotics Activity: Teams of students observe the distance to which a LEGO robot moves when hit by a ball } \\
\text { rolling down a ramp at different inclines and discuss the relationship between the height of the ramp and the } \\
\text { distance travelled by the robot. }\end{array}$} \\
\hline & \multicolumn{3}{|c|}{$\begin{array}{l}\text { 5E Model: } \\
\text { Engage: Students discuss forms of energy present in a LEGO robot when it is moving or standing still. } \\
\text { Explore: Students determine the relationship between velocity and kinetic energy using a LEGO robot. } \\
\text { Explain: Students observe and identify how energy can be transferred using a LEGO robot. } \\
\text { Elaborate: Students investigate how kinetic energy of a LEGO robot changes for different inclined surfaces. } \\
\text { Evaluate: Students determine different means to increase the total energy of a LEGO robot. }\end{array}$} \\
\hline & \multicolumn{3}{|c|}{ Topic: Animal cell } \\
\hline & \multicolumn{3}{|l|}{ Grade/Grade Band } \\
\hline & \multicolumn{3}{|c|}{$\begin{array}{l}\text { Lesson Description: Students investigate major organelles of an animal cell, i.e. nucleus, mitochondria, } \\
\text { ribosomes, cell membrane, and their important functions. Students also explore the structure of tissues, organs, } \\
\text { organ systems and organism. }\end{array}$} \\
\hline & \multicolumn{3}{|c|}{ Performance Expectation(s): MS-LS1-2 } \\
\hline & $\begin{array}{l}\text { Science \& Engineering Practices } \\
\text { (SEPs) }\end{array}$ & Disciplinary Core Ideas (DCIs) & Crosscutting Concepts (CCCs) \\
\hline & Developing and Using Models & LS1.A: Structure and Function & Structure and Function \\
\hline & \multicolumn{3}{|c|}{$\begin{array}{l}\text { Common Core State Standards (CCSS) } \\
\text { ELA/Literacy - SL.8.5 } \\
\text { Mathematics - 6.EE.C.9 }\end{array}$} \\
\hline & \multicolumn{3}{|c|}{$\begin{array}{l}\text { Robotics Activity: Students form a visual model regarding the formation of an organism from tissues, organ, } \\
\text { and organ systems by observing the LEGO robot as it moves along a straight-line path and displays each label } \\
\text { in a sequential manner. The robot is also programmed to identify and display the names of various (color- } \\
\text { coded) cell organelles by driving around inside a large diagram of an animal cell drawn on a piece of poster } \\
\text { paper and placed on the ground. }\end{array}$} \\
\hline & \multicolumn{3}{|c|}{$\begin{array}{l}\text { 5E Model: } \\
\text { Engage: Students observe life cycle of monarch butterfly and discuss its growth. } \\
\text { Explore: Students determine the relationship between cells, tissues, organs, organ } \\
\text { LEGO robots. } \\
\text { Explain: Students investigate the structure of an animal cell using LEGO robots. } \\
\text { Elaborate: Students discuss the differences between animal and plant cells. } \\
\text { Evaluate: Students identify the effects of failure of specific cell organelles on th }\end{array}$} \\
\hline
\end{tabular}


Table A.2: Details of robotics-based NGSS-plus-5E lessons created by Teachers in Phase II

\begin{tabular}{|c|c|c|c|}
\hline F & \multicolumn{3}{|c|}{ Lesson } \\
\hline \multirow[t]{9}{*}{1} & \multicolumn{3}{|l|}{ Topic: Friction and Speed } \\
\hline & \multicolumn{3}{|l|}{ Grade/Grade Band: $6^{\text {th }}-8^{\text {th }}$} \\
\hline & \multicolumn{3}{|c|}{$\begin{array}{l}\text { Lesson Description: Students explore concepts such as speed by plotting graphs of the distance travelled by a } \\
\text { LEGO robot at different times on the same surface. Students also compare the speed of the robot on different } \\
\text { surfaces and identify the impact of frictional force exerted. }\end{array}$} \\
\hline & \multicolumn{3}{|c|}{ Performance Expectation(s): MS-PS3-1, MS-PS2-2 } \\
\hline & $\begin{array}{l}\text { Science \& Engineering Practices } \\
\text { (SEPs) }\end{array}$ & Disciplinary Core Ideas (DCIs) & Crosscutting Concepts (CCCs) \\
\hline & $\begin{array}{l}\text { MS-PS3-1: Analyzing and } \\
\text { Interpreting Data } \\
\text { MS-PS2-2: Planning and Carrying } \\
\text { Out Investigations }\end{array}$ & $\begin{array}{l}\text { MS-PS3-1 } \\
\text { PS3.A: Definitions of Energy } \\
\text { MS-PS2-2 } \\
\text { PS2. A: Forces and Motion }\end{array}$ & $\begin{array}{l}\text { MS-PS3-1: Scale, Proportion, and } \\
\text { Quantity } \\
\text { MS-PS2-2: Stability and Change }\end{array}$ \\
\hline & \multicolumn{3}{|c|}{$\begin{array}{l}\text { Common Core State Standards (CCSS) } \\
\text { ELA/Literacy - RST.6-8.1, RST.6-8.3, RST.6-8.7; WHST.6-8.7 } \\
\text { Mathematics - MP.2, 6.EE.A.2, 6.RP.A.2, 7.EE.B.3, 7.EE.B.4, 7.RP.A.2, 8.EE.A.1, 8.EE.A.2, 8.F.A.3 }\end{array}$} \\
\hline & \multicolumn{3}{|c|}{$\begin{array}{l}\text { Robotics Activity: Students observe the distance travelled by the LEGO robot over different types of surfaces } \\
\text { for fixed periods, and use the data collected to calculate the speed of the robot and plot distance-vs-time graphs. } \\
\text { They discuss how the friction affects the motion of the robot. }\end{array}$} \\
\hline & \multicolumn{3}{|c|}{$\begin{array}{l}\text { 5E Model: } \\
\text { Engage: Students observe images of skaters and identify how they utilize their body to modify speed of } \\
\text { skateboards. } \\
\text { Explore: Students determine average speed of a LEGO robot moving on different surfaces. } \\
\text { Explain: Students brainstorm reasons to explain the changes in speeds of the robots on different surfaces. } \\
\text { Elaborate: Groups of students modify LEGO robots such that they can travel faster. } \\
\text { Evaluate: Students discuss how different environmental conditions can affect speed of vehicles on roads. }\end{array}$} \\
\hline \multirow[t]{9}{*}{2} & \multicolumn{3}{|l|}{ Topic: Genetic Mutations } \\
\hline & \multicolumn{3}{|l|}{ Grade/ Grade Band: $8^{\text {th }}$} \\
\hline & \multicolumn{3}{|c|}{$\begin{array}{l}\text { Lesson Description: Students, as genetic counsellors, use LEGO robots to analyze patient specific genetic } \\
\text { information presented to them and investigate if DNA point mutations are present. Students cross-reference } \\
\text { patient medical history and their genetic test results to diagnose whether patients have a genetic disorder or not. } \\
\text { For enrichment, students analyze and interpret data from the Center for Disease Control on the recent rates of } \\
\text { deaths caused by cancer in males and females in (this) State. }\end{array}$} \\
\hline & \multicolumn{3}{|c|}{ Performance Expectation(s): MS-LS3-1 } \\
\hline & $\begin{array}{l}\text { Science } \\
\text { (SEPs) }\end{array}$ & CIs) & Cs) \\
\hline & Developing and Using Models & LS3.A: Inheritance of Traits & \\
\hline & \multicolumn{3}{|c|}{$\begin{array}{l}\text { Common Core State Standards (CCSS) } \\
\text { ELA/Literacy - RST.6-8.1, RST.6-8.4, RST.6-8.7, SL.8.5 } \\
\text { Mathematics - MP.4, 6.SP.B.5, 7.RP.2, 7.RP.A.3 }\end{array}$} \\
\hline & \multicolumn{3}{|c|}{$\begin{array}{l}\text { Robotics Activity: Each group of students receive a poster paper with a pre-drawn model of an individual's } \\
\text { genome. Robot moves along the length of the genome and stops at pre-programmed positions (indicating the } \\
\text { chromosome(s) where the mutations(s) are located) to indicate an error, which is recorded by the students. } \\
\text { Then they study the details of several diseases and compare them with patient medical history cards provided } \\
\text { to them as well as the data collected to determine if a patient has certain genetic disorders/outcomes. }\end{array}$} \\
\hline & \multicolumn{3}{|c|}{$\begin{array}{l}\text { 5E Model: } \\
\text { Engage: Students identify differences in images of karyotypes belonging to a male and female subject. } \\
\text { Explore: Students use a LEGO robot to observe if and where certain genomes provided to them have mutations. } \\
\text { Explain: Students determine if the presence of mutation on a genome always leads to disorder in a person. } \\
\text { Elaborate: Students compare and contrast mortality rates due to commonly diagnosed cancers in men and } \\
\text { women using Center for Disease Control data. } \\
\text { Evaluate: Students discuss pros and cons of genetic screening and testing. }\end{array}$} \\
\hline
\end{tabular}




\begin{tabular}{|c|c|c|c|}
\hline & \multirow{2}{*}{\multicolumn{3}{|c|}{ sistance }} \\
\hline & & & \\
\hline & \multicolumn{3}{|c|}{$\begin{array}{l}\text { Lesson Description: Students investigate causes for the predominance or suppression of certain traits in a } \\
\text { bacterial population and study the impact of an antibiotic on a bacterial population over many generations. } \\
\text { Students also develop a list of criteria and constraints for solutions to combat antibiotic resistance in hospitals } \\
\text { or other places that see large numbers of sick or elderly people. }\end{array}$} \\
\hline & \multicolumn{3}{|c|}{ Performance Expectation(s): MS-LS4-4, MS-LS4-6 } \\
\hline & $\begin{array}{l}\text { Science \& Engineering Practices } \\
\text { (SEPs) }\end{array}$ & Disciplinary Core Ideas (DCIs) & Crosscutting Concepts (CCCs) \\
\hline & $\begin{array}{l}\text { MS-LS4-4: Constructing } \\
\text { Explanations and Designing } \\
\text { Solutions } \\
\text { MS-LS4-6: Mathematics and } \\
\text { Computational Thinking }\end{array}$ & $\begin{array}{l}\text { MS-LS4-4 } \\
\text { LS4.B: Natural Selection } \\
\text { MS-LS4-6 } \\
\text { LS4.C: Adaptation }\end{array}$ & Cause and Effect \\
\hline & \multicolumn{3}{|c|}{$\begin{array}{l}\text { Common Core State Standards (CCSS) } \\
\text { ELA/Literacy - RST.6-8.1, RST.6-8.9, WHST.6-8.9, SL.8.1, SL.8.4 } \\
\text { Mathematics - 6.RP.A.1, 6.SP.B.5, 7.RP.A.2; MP.4 }\end{array}$} \\
\hline & \multicolumn{3}{|c|}{$\begin{array}{l}\text { Robotics Activity: Students observe the sector angle spanned by a LEGO robot rotating about its center of } \\
\text { mass to calculate the proportion of a petri dish occupied by a certain strain of bacteria. They correlate the } \\
\text { reproductive advantage that each strain of bacteria has based on a dominant trait assigned to it, such as growing } \\
\text { and dividing quickly or slowing down of the cell death process. }\end{array}$} \\
\hline & \multicolumn{3}{|c|}{$\begin{array}{l}\text { 5E Model: } \\
\text { Engage: Students discuss need for antibiotics and antibiotic resistance. } \\
\text { Explore: Students determine probabilities for frequency of traits of bacteria using a LEGO robotics activity. } \\
\text { Explain: Students investigate the role of natural selection in explaining the frequency of traits in bacteria. } \\
\text { Elaborate: Students identify the most effective antibiotic to treat a disease based on data provided. } \\
\text { Evaluate: Students formulate an explanation for how overuse of antibiotics can increase bacterial resistance. }\end{array}$} \\
\hline & \multicolumn{3}{|l|}{ Topic: Cell Transport } \\
\hline & \multicolumn{3}{|l|}{ Grade/ Grade Band: $7^{\text {th }}$} \\
\hline & \multicolumn{3}{|c|}{ Lesson Description: Students investigate the effect of relative concentrations in cell transport. } \\
\hline & \multicolumn{3}{|c|}{ Performance Expectation(s): MS-LS1-2 } \\
\hline & $\begin{array}{l}\text { Science \& Engineering Practices } \\
\text { (SEPs) }\end{array}$ & Disciplinary Core Ideas (DCIs) & Crosscutting Concepts (CCCs) \\
\hline & Developing and Using Models & LS1.A: Structure and Function & Structure and Function \\
\hline & \multicolumn{3}{|l|}{$\begin{array}{l}\text { ELA/Literacy - SL. } 8.5 \\
\text { Mathematics - 6.EE.C.9 }\end{array}$} \\
\hline & \multicolumn{3}{|c|}{$\begin{array}{l}\text { Robotics Activity: Students are given a poster paper with a line representing cell membrane and with regions } \\
\text { labeled as "inside" and "outside" of a cell. The pre-programmed LEGO robot represents a molecule at the cell } \\
\text { membrane and moves in the proper direction (into the cell or out of the cell) based on data input provided by } \\
\text { students. }\end{array}$} \\
\hline & \multicolumn{3}{|c|}{$\begin{array}{l}\text { 5E Model: } \\
\text { Engage: Students discuss if a dehydrated castaway can drink seawater to survive. } \\
\text { Explore: Students determine the conditions needed for a LEGO robot to move in or out of the cell. } \\
\text { Explain: Students investigate uses of salt for gargling and preserving food based on osmosis. } \\
\text { Elaborate: Students predict movement of a LEGO robot based on given intracellular and extracellular } \\
\text { concentrations and use the robot to verify and validate their responses. } \\
\text { Evaluate: Students explain dispersion of a drop of ink in a glass of water. }\end{array}$} \\
\hline
\end{tabular}


Table A.3: Comparison of details of an 'old' robotics-based lesson with a 'new' NGSS-plus-5E lesson created during the PD

\begin{tabular}{|c|c|c|}
\hline Item & Old Lesson & NGSS-plus-5E aligned lesson \\
\hline Topic & \multicolumn{2}{|l|}{ Scale of Solar System } \\
\hline NGSS & \multicolumn{2}{|l|}{ MS-ESS1-3 } \\
\hline $\mathbf{P E}$ & \multicolumn{2}{|c|}{$\begin{array}{l}\text { Analyze and interpret data to determine scale properties of objects in the solar system. } \\
\text { [Clarification Statement: Emphasis is on the analysis of data from Earth-based instruments, space- } \\
\text { based telescopes, and spacecraft to determine similarities and differences among solar system } \\
\text { objects. Examples of scale properties include the sizes of an object's layers (such as crust and } \\
\text { atmosphere), surface features (such as volcanoes), and orbital radius. Examples of data include } \\
\text { statistical information, drawings and photographs, and models.] [Assessment Boundary: } \\
\text { Assessment does not include recalling facts about properties of the planets and other solar system } \\
\text { bodies.] }\end{array}$} \\
\hline $\begin{array}{l}\text { Lesson } \\
\text { Objective }\end{array}$ & $\begin{array}{l}\text { Students will be able to plot relative spacing } \\
\text { between the planets in our solar system to } \\
\text { demonstrate at least } 80 \% \text { mastery of scale and } \\
\text { proportion. }\end{array}$ & $\begin{array}{l}\text { Students will learn how to use scaled models to } \\
\text { simulate the behavior of a large system, i.e. the } \\
\text { solar system, and to record and interpret } \\
\text { observations made with a scaled model. }\end{array}$ \\
\hline \multirow[t]{2}{*}{ DCI } & \multicolumn{2}{|c|}{$\begin{array}{l}\text { ESS1.B: Earth and the Solar System } \\
\text { The solar system consists of the sun and a collection of objects, including planets, their moons, and } \\
\text { asteroids that are held in orbit around the sun by its gravitational pull on them. }\end{array}$} \\
\hline & $\begin{array}{l}\text { Teachers provide a word bank of names of } \\
\text { planets on the board and ask students to plot } \\
\text { where they think the planets are on a graph } \\
\text { paper. }\end{array}$ & $\begin{array}{l}\text { Teachers engage students in a discussion of the } \\
\text { solar system, and the relative proximity of } \\
\text { different planets to the sun. }\end{array}$ \\
\hline \multirow[t]{2}{*}{ SEP } & \multicolumn{2}{|c|}{$\begin{array}{l}\text { Analyzing and Interpreting Data } \\
\text { Analyze and interpret data to determine similarities and differences in findings. }\end{array}$} \\
\hline & $\begin{array}{l}\text { Students find the location of an asteroid } \\
\text { 'Psyche' in relation to the distance of the earth } \\
\text { from the sun and plan a mission to the asteroid } \\
\text { for mining purposes. }\end{array}$ & $\begin{array}{l}\text { Students infer the order of the planets in the solar } \\
\text { system based their orbital periods. } \\
\text { Teachers inform the students about inner/outer } \\
\text { planets, terrestrial/Jovian planets and discuss the } \\
\text { variations in composition, atmosphere etc. } \\
\text { between them and illustrate how proximity from } \\
\text { sun gives rise to different features of the planets. }\end{array}$ \\
\hline \multirow[t]{2}{*}{$\mathrm{CCC}$} & \multicolumn{2}{|c|}{$\begin{array}{l}\text { Scale, Proportion, and Quantity } \\
\text { Time, space, and energy phenomena can be observed at various scales using models to study } \\
\text { systems that are too large or too small. }\end{array}$} \\
\hline & $\begin{array}{l}\text { Students use actual orbital distance data to } \\
\text { calculate and plot scaled distances of the planets } \\
\text { to the sun on a line graph. The LEGO robot is } \\
\text { pre-programmed to move in a straight line and } \\
\text { stop at different points indicating the position of } \\
\text { planets. Students use this to check their } \\
\text { calculations. }\end{array}$ & $\begin{array}{l}\text { Students observe time taken by a LEGO robot } \\
\text { (displaying the name of each of the four inner } \\
\text { planets on the EV3 brick) to complete one orbit } \\
\text { around a selected point (sun). Given the actual } \\
\text { orbital period of Earth, students work in groups } \\
\text { to calculate the orbital periods of the other three } \\
\text { planets based on the data collected. }\end{array}$ \\
\hline $\begin{array}{l}\text { Common } \\
\text { Core }\end{array}$ & $\begin{array}{l}\text { ELA/Literacy - RST.9-10.1 } \\
\text { Mathematics - N/A }\end{array}$ & $\begin{array}{l}\text { ELA/Literacy - RST.6-8.1, RST.6-8.7 } \\
\text { Mathematics - MP.2, 6.RP.A.1, 7.RP.A.2 }\end{array}$ \\
\hline
\end{tabular}

